\title{
PENGALAMAN PARA PIONER HARIAN JAWA POS ERA KEMBANG JEPUN 1982 DALAM MEMBANGUN KEJAYAAN JAWA POS (Studi Fenomenologis Masa Awal Perkembangan Jawa Pos)
}

\author{
Dhimam Abror \\ STIKOSA-AWS Surabaya \\ Jl. Nginden Intan Timur I/18, Surabaya, INDONESIA \\ Email: d.abror@yahoo.com
}

\begin{abstract}
ABSTRAK
Dari sebuah bangunan tua di Jl Kembang Jepun, sebuah daerah bagian utara Surabaya yang kumuh, sekelompok wartawan pada awal 1982 mulai membuat sejarah. Harian Pagi Jawa Pos Surabaya, yang semula dimiliki oleh pengusaha Cina The Cung Sen, beralih kepemilikan setelah diakusisi oleh PT Grafitti Pers, penerbit majalah mingguan Tempo. Dahlan Iskan, kepala biro Tempo di Jawa Timur ditugasi menjadi pemimpin redaksi Jawa Pos. Bersama beberapa wartawan lama Jawa Pos, Dahlan mulai membangun Jawa Pos hampir dari nol untuk kemudian, dalam waktu dua puluh tahun menjadi konglomerasi surat kabar terbesar di Indonesia. Penelitian ini akan mengungkap masa-masa awal periode Kembang Jepun (kantor pusat Jawa Pos) 1982 di mata delapan wartawan pioner Jawa Pos. Studi fenomenologis ini akan fokus pada makna pengalaman mereka pada masa-masa awal perjuangan itu. Dari pengalaman fenomenologis para pioner itu terungkap bahwa sejak era Kembang Jepun itu 'Rukun Iman Jawa Pos", enam prinsip nilai berita Jawa Pos, dimunculkan, ditanamkan, dan terus-menerus diinternalisasikan. Rukun Iman Jawa Pos inilah yang menjadi ciri khas redaksional Jawa Pos dan diyakini menjadi resep rahasia keberhasilan Jawa Pos menjadi koran terbesar di Jawa Timur dan kemudian konglomerasi media terbesar di Indonesia.
\end{abstract}

Kata kunci: Nilai berita, pengalaman jurnalistik, konglomerasi, dominasi pasar media.

\begin{abstract}
From an old building at $J$ Kembang Jepun, a slump area of northern part of Surabaya, a group of journalists started to make history in 1982. Jawa Pos Daily, a nearly bankrupt newspaper owned by a Chinese businessman named The Cung Sen, was taken over by PT Grafitti Pers, publisher of highly respected news weekly Tempo of Jakarta. Dahlan Iskan, head of East Java Bureau of Tempo was appointed as editor of Jawa Pos. Together with some old journalists of Jawa Pos Dahlan started to bulid Jawa Pos from a scratch. In two decades it becomes the largest media conglomerate in Indonesia. This research tries to reveal early days of period of Kembang Jepun, then Jawa Pos head office, in the eyes of eight pioneer journalists of Jawa Pos. This phenomenology study focuses on the meaning of their experience from the early periods of their struggle, until become the largest newspaper in East Java and finally a leading media conglomerate in Indonesia. Thru their experiences it is revealed that from those early days of Kembang Jepun era, 'The Six Principles of Faith" (referred to Islamic Faith) have been introduced, socialized, and thouroughly internalized as core and main news values of Jawa Pos. The Six Principles of Faith are believed to be the secret formula behind the success of Jawa Pos as the dominant media in East Java and later the largest media conglomerate in Indonesia.
\end{abstract}

Keywords: Conglomeration, media acquisition, market dominance, journalistic experience.

\section{PENDAHULUAN}

Surat kabar Harian Jawa Pos merupakan konglomerasi surat kabar terbesar di Indonesia. Membawahi lebih dari 160 surat kabar lokal di Indonesia membuat Jawa Pos menjadi surat kabar yang memiliki jaringan terbesar di Indonesia.

Surat kabar ini didirikan pada 1 juli 1949, dan diterbitkan oleh PT. Perusahaan dan Penerbitan Java Pos yang dipimpin oleh The Chung Sen alias Soeseno seorang warga Indonesia kelahiran Bangka, Sumatra Selatan.

The Chung Sen awalnya bekerja di sebuah kantor film di Surabaya. Dia memiliki tugas untuk menghubungi surat kabar untuk memuat iklan tentang film yang dibuat oleh kantornya yang dimuat di surat kabar tersebut. Dari situlah The Chung Sen mengetahui bahwa memiliki surat kabar ternyata menguntungkan, maka didirikanlah Jawa Pos. Jawa Pos semula berdiri dengan nama Java Pos (1949-1954), 
yang kemudian berubah menjadi Djawa Post (19541957), berganti lagi menjadi Djawa Pos (1957-1960), dan akhirnya diubah kembali menjadi Jawa Pos sejak tahun 1960 hingga sekarang.

Jawa Pos juga termasuk salah satu surat kabar tertua di Indonesia. Kesuksesan bisnis yang dilakoni The Chung Sen tidak selamanya berjalan mulus. Pada akhir 1970-an, penghasilan Jawa Pos menurun drastis. Tahun 1982, oplahnya hanya tinggal 6.700 eksemplar setiap harinya, hal ini disebabkan adanya perkembangan teknologi cetak yang kian sulit untuk diikuti. The Chung Sen memutuskan untuk menyerahkan pengelolaan Jawa Pos kepada pengelola majalah mingguan berita Tempo pada 1 April 1982.

Kepala Biro Tempo Jawa timur, Dahlan Iskan dipilih untuk memimpin Jawa Pos. Dalam waktu relatif singkat ia berhasil membawa Jawa Pos yang hampir mati dengan oplah hanya 6000 eksemplar, dalam waktu sepuluh tahun meningkat menjadi surat kabar dengan oplah .menembus 100.000 eksemplar.

Pada awal 1990-an terbentuklah Jawa Pos News Network (JPNN), untuk mewadahi jaringan anak perusahaan JP yang sudah mulai menyebar ke berbagai daerah. Dalam tempo satu dekade berikutnya, JP menjadi salah satu jaringan surat kabar terbesar di Indonesia, memiliki lebih dari 80 surat kabar, tabloid dan majalah, serta 40 jaringan percetakan di Indonesia. Pada tahun 1997, Jawa Pos pindah ke gedung baru di gedung Graha Pena salah satu gedung pencakar langit di Surabaya. Gedung ini selesai dibangun di tengah krisis yang sedang melanda Indonesia, hal ini membuktikan kesuksesan Jawa Pos melawan krisis yang sedang terjadi.

Jawa Pos Group merupakan jaringan surat kebar terbesar di Indonesia dengan menaungi 170 surat kabar dan stasiun televisi diseluruh Indonesia. Jawa Pos tidak hanya merupakan surat kabar pertama yang mengembangkan jaringan surat kabar di Indonesia, tetapi juga salah satu surat kabar yang mendirikan chanel televisi lokal di Indonesia. Pada tahun 2002, Riau TV di Pekanbaru menjadi stasiun televisi lokal pertama di Indonesia. Kemudian menyusul Batam TV di Batam dan JTV di Surabaya. Pada tahun 2008, Jawa Pos Group telah memiliki 12 stasiun televisi lokal dan naik menjadi 20 televisi lokal pada akhir 2009.

Jawa Pos Group juga menaungi kurang lebih 151 surat kabar daerah dan nasional yang tersebar di seluruh wilayah Indonesia. Surat kabar daerah yang berada di bawah naungan Jawa Pos Group biasanya memiliki nama berawalan dengan "Radar", seperti Radar Bandung, Radar Solo, Radar Surabaya, Radar, Lampung, Radar Banjarmasin, dan sebagainya. Dilihat dari sisi manajemen, koran "Radar" yang tersebar dibanyak wilayah Indonesia dikelola secara otonom oleh masing-masing manajemen Radar.

Jawa Pos juga telah berhasil meraih beberapa penghargaan, di antaranya Indonesia Best Brand (2007), Superbrands Indonesia's Chioce (2010-2011), Greates Brand People's Choice (2010), Indonesian Most Favorite Brand (2011), Women Brand (2011), Best Design in Asian Media Awards (2012), World Young Reader Newspaper of the Year (2011) dan beberapa penghargaan lainnya.

Jawa pos telah membuktikan bahwa kesuksesan membangun sebuah "kerajaan" media membutuhkan kerja keras dari segenap komponen dan organisasi dari media sejak masa-masa awal. Keberhasilan Dahlan Iskan karena memiliki keberanian mengambil risiko yang terukur dan kerja keras, serta kepiawaian membaca peluang. Dan yang paling penting adalah keberhasilan Dahlan dalam merumuskan kebijakan redaksional yang sederhana dan praktis, tetapi sangat mengena bagi selera masyarakat Jawa Timur. Bahasa yang ditampikan Jawa Pos sederhana dan mengalir seperti orang bercerita. Dalam bahasa Dahlan, gaya penulisan Jawa Pos adalah 'menceritakan" peristiwa, bukan sekadar melaporkan peristiwa. (Intarto, 2005).

Resep rahasia itu baru beberapa tahun kemudian dinamakan sebagai 'Rukun Iman" yang menjadi panduan utama pemuatan berita-berita Jawa Pos. Rukun Iman tersebut adalah:

1. Rukun pertama, ketokohan (Prominence). Semua peristiwa menyangkut tingkah polah seorang tokoh layak berita. Misalnya, Gubernur Jawa Timur masuk rumah sakit karena demam berdarah. Ini layak diberitakan.

2. Rukun kedua, besar (Magnitude). Semua peristiwa yang besar layak berita. Misalnya, gempa bumi menyebabkan kerugian yang besar. Ini layak berita.

3. Rukun Ketiga, dekat (Proximity). Semua peristiwa yang terjadi di dekat kita, meskipun kecil layak berita dibanding peristiwa serupa yang lebih besar tetapi di tempat yang jauh. Misal, gempa di Jawa Timur korbannya 10 orang lebih layak diberitakan, ketimbang gempa di Amerika Latin yang menelan korban 100 orang. Kalau pun keduanya perlu diberitakan, gempa di Jawa Timur harus lebih besar dan lengkap. 
4. Rukun keempat, tren baru (Trend). Semua peristiwa yang baru pertama terjadi, layak berita. Misal, ada pencurian dengan modus baru yang baru pertama terjadi. Walau kerugiannya kecil, peristiwa itu layak berita.

5. Rukun kelima, daya taik manusia (Human Interest). Semua peristiwa yang menyentuh perasaan kemanusiaan, layak diberitakan. Semua berita yang berkisah mengenai manusia menarik diikuti karena pada dasarnya manusia suka mendengar dan membicarakan orang lain.

6. Rukun keenam, bermisi (Mission). Setiap berita harus memiliki misi atau tujuan. Misalnya, mencerdaskan, mendidik dan memotivasi masyarakat untuk kebaikan.

Menurut Dahlan, semua wartawan saat meliput peristiwa harus menemukan sebanyak mungkin rukun iman berita itu. Semakin banyak rukunnya, semakin layak beritanya. Demikian pula sebaliknya. (Intarto, 2005)

\subsection{Fokus Penelitian}

Dari latar belakang masalah di atas, maka rumusan masalah dalam penelitian ini adalah "Bagaimana pengalaman wartawan Jawa Pos era Kembang Jepun dalam membangun kejayaan media massa pada Masa Awal Perkembangan Jawa Pos"

\subsection{Identifikasi Masalah}

Bersadarkan latar belakang dan rumusan masalah yang telah dikemukakan masalah dapat diidentifikasikan sebagai berikut:

1. Bagaimana Pengalaman-pengalaman yang diperoleh selama menjadi wartawan Jawa Pos pada awal perkembangannya.

2. Bagaimana pengalaman mereka dalam ikut serta merumuskan formula redaksional untuk menghadapi persaingan.

3. Bagaimana pengalaman mereka mendapatkan nilai-nilai kerja keras tak kenal menyerah untuk memenangkan persaingan.

\subsection{Tujuan Penelitian}

Secara umum penelitian ini bermaksud untuk menganalisis dan mendeskripsikan pengalaman-pengalaman yang diperoleh alumnus wartawan Jawa Pos yang ikut andil dalam membangun kesusksesan Jawa Pos.

Sedangkan tujuan yang ingin diperoleh dari penelitian ini adalah: a. Mengetahui Pengalaman-pengalaman apa saja yang diperoleh alumnus wartawan Jawa Pos pada awal perkembangannya.

b. Mengungkap bagaimana pengalaman para pioner dalam keterlibatannya merumuskan dan menjalankan formula redaksional untuk memenangkan persaingan.

c. Mengetahui bagaimana pengalaman para pioner dalam mendapatkan nilai-nilai kerja keras pantang menyerah untuk memenangkan persaingan.

\section{KAJIAN PUSTAKA}

\subsection{Pengalaman}

Menurut Endarmoko (2006) pengalaman berasal dari kata "alami", yang artinya melakoni, mengalami, menempuh, mengarungi, menghadapi, menyebrangi, menanggung, mendapat, menyelami, dan merasakan (dalam Abadi, 2013: 67).

Pengalaman ialah hasil persentuhan alam dengan panca indra manusia. Setiap pengalaman akan memberikan makna baru bagi yang mengalaminya dan begitu seterusnya. Dengan demikian makna tersebut yang dintepretasi oleh individu akan berubah terus menerus sepanjang hidupnya seiring dengan setiap pengalaman baru yang ditemui oleh individu tersebut dan makna yang diberikannya terhadap pengalaman baru tersebut.

Moustakas (dalam Wirman, 2002: 52) mengatakan bahwa "all objects of knowledge must conform to experience", pengetahuan melandasi kesadaran yang membentuk pemaknaan. Kesadaran dan pemaknaan inilah yang mendorong individu untuk melakukan tindakan atau perilaku tertentu.

Schutz (dalam Wirman, 2012: 52) mengatakan "behavior is an experience of consciousness that bestows meaning through spontaneous activity", setiap peristiwa yang dialami akan menjadi sebuah pengalaman bagi individu. Pengalaman yang diperoleh mengandung suatu informasi atau pesan tertentu. Informasi ini akan diolah menjadi pengetahuan. Dengan demikian berbagai peristiwa yang dialami dapat menambah pengetahuan individu.

\subsection{Pengetahuan}

Menurut Notoatmodjo (2007), pengetahuan adalah merupakan hasil dari tahu, dan ini setelah orang melakukan penginderaan terhadap obyek tertentu. Penginderaan terjadi melalui panca indera manusia, 
yakni indera penglihatan, pendengaran, penciuman, rasa dan raba. Sebagaian besar pengetahuan manusia diperoleh melalui mata dan telinga. Pengetahuan atau kognitif merupakan domain yang sangat penting untuk terbentuknya perilaku seseorang (Notoatmodjo 2007).

Menurut Taufik (2007), pengetahuan merupakan penginderaan manusia, atau hasil tahu seseorang terhadap objek melalui indera yang dimilikinya (mata, hidung, telinga, dan lain sebagainya).

\subsection{Peview Penelitian Sejenis}

Tidak ada penelitian yang benar-benar mirip dengan penelitian yang akan dilakukan, namun terdapat penelitian yang menggunakan metode sama, terlihat seperti pada Tabel 1.

Tabel 1. Matriks Review Penelitian Sejenis

\begin{tabular}{|c|c|c|c|c|c|}
\hline No & Nama Peneliti & Judul Penelitian & Metodologi & Hasil & Analisis \\
\hline 1 & $\begin{array}{l}\text { Ardhita Silvada, Pra- } \\
\text { mono Benyamin, Akbar } \\
\text { (e-journal mahasiswa } \\
\text { universitas Padjadjaran } \\
\text { Vol 1. No. 1 Tahun 2012) }\end{array}$ & $\begin{array}{l}\text { Konsep Diri Pemain } \\
\text { Game Online: Studi } \\
\text { Fenomenologi tentang } \\
\text { konstruksi konsep diri } \\
\text { perempuan pecandu game } \\
\text { online di Jakarta }\end{array}$ & $\begin{array}{l}\text { Kualitatif dengan } \\
\text { Pendekatan } \\
\text { Fenomenologi }\end{array}$ & $\begin{array}{l}\text { Motif Bermain Game adalah } \\
\text { motivasi sosial dan Immersion }\end{array}$ & $\begin{array}{l}\text { Kesamaan } \\
\text { Metodologi }\end{array}$ \\
\hline 2 & $\begin{array}{l}\text { Stefanus Nindito (Jurnal } \\
\text { Ilmu Komunikasi Vol } 2 . \\
\text { No1. Juni 2005) }\end{array}$ & $\begin{array}{l}\text { Fenomenologi Alfred } \\
\text { Schutz: Studi tentang } \\
\text { Konstruksi Makna dan } \\
\text { Realitas dalam Ilmu } \\
\text { Sosial }\end{array}$ & $\begin{array}{l}\text { Kualitatif dengan } \\
\text { Pendekatan } \\
\text { Fenomenologi }\end{array}$ & $\begin{array}{l}\text { akar tradisi berpikir } \\
\text { fenomenologi ke dalam ruang } \\
\text { perdebatan yang besar tentang } \\
\text { pemikiran perilaku informasi. }\end{array}$ & $\begin{array}{l}\text { Kesamaan } \\
\text { Metodologi }\end{array}$ \\
\hline 3 & $\begin{array}{l}\text { Dwi Ramadhan Seto } \\
\text { (Jurnal Ilmiah Universitas } \\
\text { Bakrie Vol 3, No 03 } \\
(2015))\end{array}$ & $\begin{array}{l}\text { Pengalaman Dan } \\
\text { Perilaku Keluhan } \\
\text { Konsumen Yang } \\
\text { Terpendam: Studi } \\
\text { Fenomenologi }\end{array}$ & $\begin{array}{l}\text { Kualitatif dengan } \\
\text { Pendekatan } \\
\text { Fenomenologi }\end{array}$ & $\begin{array}{l}\text { faktor yang melatarbelakangi } \\
\text { konsumen dalam berperilaku } \\
\text { mengeluh, di antaranya faktor } \\
\text { agama, kultur, serta lingkung- } \\
\text { an sosial, di samping peng- } \\
\text { alaman dan persepsi pribadi. }\end{array}$ & $\begin{array}{l}\text { Kesamaan } \\
\text { Metodologi }\end{array}$ \\
\hline 4 & $\begin{array}{l}\text { Deysi Kanal, Max } \\
\text { Rembang, Johnny } \\
\text { Senduk (e-journal “Acta } \\
\text { Diurna” Volume IV. } \\
\text { No.4. Tahun 2015) }\end{array}$ & $\begin{array}{l}\text { Pemanfaatan Media } \\
\text { Alternatif Studi Penolak- } \\
\text { an Pertambangan Biji } \\
\text { Besi Di Pulau Bangka, } \\
\text { Likupang Timur, Kabu- } \\
\text { paten Minahasa Utara }\end{array}$ & $\begin{array}{l}\text { Kualitatif Dengan } \\
\text { Pendekatan } \\
\text { Fenomenologi }\end{array}$ & $\begin{array}{l}\text { Berbagai Media Alternatif } \\
\text { Yang Digunakan Dalam } \\
\text { Menyampaikan Pesan } \\
\text { Penolakan Pertambangan } \\
\text { Biji Ini Ialah Facebook, Kaos } \\
\text { \& Spanduk, Musik, Serta } \\
\text { Petisi Online }\end{array}$ & $\begin{array}{l}\text { Kesamaan } \\
\text { Metodologi }\end{array}$ \\
\hline 5 & $\begin{array}{l}\text { Merinda N., Pambudi } \\
\text { Handoyo (Jurnal } \\
\text { Paradigma Vol 2, No 3, } \\
\underline{(2014))}\end{array}$ & $\begin{array}{l}\text { Makna Penggunaan } \\
\text { Jejaring Sosial Path Bagi } \\
\text { Mahasiswa Unesa }\end{array}$ & $\begin{array}{l}\text { Kualitatif Dengan } \\
\text { Pendekatan } \\
\text { Fenomenologi }\end{array}$ & $\begin{array}{l}\text { Terdapat } 5 \text { Pemaknaan Dalam } \\
\text { Penggunaan Jejaring Sosial } \\
\text { Path. Pertama, Makna } \\
\text { Eksistensi Diri Kedua, Makna } \\
\text { Aktualisasi Diri Ketiga, } \\
\text { Makna Informasi Keempat, } \\
\text { Makna Hiburan Kelima, } \\
\text { Makna Komunikasi Dan } \\
\text { Menjalin Silahturahmi }\end{array}$ & $\begin{array}{l}\text { Kesamaan } \\
\text { Metodologi }\end{array}$ \\
\hline 6 & Robiatul Auliyah & $\begin{array}{l}\text { Studi Fenomenologi } \\
\text { Peranan Manajemen } \\
\text { Masjid At-Taqwa } \\
\text { Dalam Pemberdayaan } \\
\text { Ekonomi Masyarakat } \\
\text { Bangkalan }\end{array}$ & $\begin{array}{l}\text { Kualitatif dengan } \\
\text { Pendekatan } \\
\text { Fenomenologi }\end{array}$ & $\begin{array}{l}\text { Peranan Manajemen Masjid } \\
\text { tidak Opitmal }\end{array}$ & $\begin{array}{l}\text { Kesamaan } \\
\text { Metodologi }\end{array}$ \\
\hline 7 & $\begin{array}{l}\text { Friska Berliana Pakpahan } \\
\text { (eJournal Ilmu Komuni- } \\
\text { kasi, 2013, } 1 \text { (3): } 234 \text { - } \\
\text { 248) }\end{array}$ & $\begin{array}{l}\text { Fungsi Komunikasi Antar } \\
\text { Budaya dalam Prosesi } \\
\text { Pernikahan Adat Batak }\end{array}$ & $\begin{array}{l}\text { Kualitatif dengan } \\
\text { Pendekatan } \\
\text { Fenomenologi }\end{array}$ & $\begin{array}{l}\text { Komunikasi Antar Budaya } \\
\text { sangat dibutuhkan dalam } \\
\text { proses pernikahan berbeda } \\
\text { etnis. }\end{array}$ & $\begin{array}{l}\text { Kesamaan } \\
\text { Metodologi }\end{array}$ \\
\hline
\end{tabular}




\section{LANDASAN TEORETIS}

\subsection{Teori Fenomenologi}

Fenomenologi berupaya mengungkapkan dan memahami realitas penelitian berdasarkan perspektif subjek penelitian. Seperti yang dikemukakan oleh Bogdan dan Taylor: "The fenomenologist is concerned with understanding human behavior from the actor's own frame of reference" Bogdan dan Taylor (1975:2).

Hal ini menuntut bersatunya subyek peneliti dengan subyek pendukung obyek penelitian. Keterlibatan subyek peneliti di lapangan menghayatinya menjadi salah satu ciri utama penelitian dengan pendekatan fenomenologi.

Fenomenologi yang digunakan dalam penelitian ini dalam perspektif Alfred Schutz yang lebih menekankan pada pentingnya intersubjektivitas. Inti dari fenomenologi Schutz adalah memandang bahwa pemahaman atas tindakan, ucapan, dan interaksi merupakan prasyarat lagi eksistensi sosial apapun (Mulyana, 2001:62).

Schutz menjelaskan bahwa, "Fenomenologi mengkaji bagaimana anggota masyarakat menggambarkan dunia sehari-harinya, terutama bagaimana individu dengan kesadarannya membangun makna dari hasil interaksi dengan individu lainnya". (Cresswell, 1998:53)

Penelitian fenomenologi pada hakikatnya adalah berhubungan dengan interpretasi terhadap realitas. Fenomenologi mencari jawaban tentang makna dari suatu fenomena. Pada dasarnya, ada dua hal utama yang menjadi fokus dalam penelitian fenomenologi yakni:

a. Textual description: apa yang dialami oleh subjek penelitian tentang sebuah fenomena. Apa yang dialami adalah aspek objektif, data yang bersifat faktual, hal yang terjadi secara empiris.

b. Structural description: bagaimana subjek mengalami dan memaknai pengalamannya. Deskripsi ini berisi aspek subjektif. Aspek ini menyangkut pendapat, penilaian, perasaan, harapan, serta respons subjektif lainnya dari subjek penelitian berkaitan dengan pengalamannya itu (Hasbiansyah, 2008:171).

Berikut tiga prinsip dasar fenomenologi yang dikemukakan oleh Deetz, yaitu:

(1) Bahwa pengetahuan tidak dapat ditemukan dalam pengalaman eksternal tetapi dalam diri kesadaran individu. Jadi, fenomenologi lebih mengitari penelitian untuk pemahaman subjektif ketimbang mencari objektivitas sebab akibat dan penjelasan universal.

(2) Makna adalah derivasi dari potesialitas dari sebuah objek atau pengalaman yang khusus dari kehidupan pribadi. Dalam artian, makna yang berasal dari suatu objek atau pengalaman akan bergantung pada latar belakang individu dan kejadian tertentu dalam hidup.

(3) Kalangan fenomenolog percaya bahwa dunia alami dan makna, dibangun melalui bahasa. (Ardianto dan Q-Anees, 2007 : 127, 128) Schutz, sebagai orang pertama yang menerapkan fenomenologi dalam penelitian ilmu sosial mengatakan, baginya tugas fenomenologi adalah menghubungkan antara pengetahuan ilmiah dengan pengalaman sehari-hari, dan dari kegiatan dimana pengalaman dan pengetahuan itu berasal. Dengan kata lain mendasarkan tindakan sosial pada pengalaman, makna, dan kesadaran.

Inti pemikiran Schutz adalah bagaimana memahami tindakan sosial melalui penafsiran. Proses penafsiran dapat digunakan untuk memperjelas atau memeriksa makna yang sesungguhnya, sehingga dapat memberikan konsep kepekaan yang implisit. Schutz meletakkan hakikat manusia dalam pengalaman subjektif, terutama ketika mengambil tindakan dan mengambil sikap terhadap dunia kehidupan sehari-hari. Dalam hal ini, Schutz mengikuti pemikiran Husserl, yaitu proses pemahaman aktual kita, dan pemberian makna terhadapnya, sehingga ter-refleksi dalam tingkah laku (Kuswarno, 2009: 18).

\subsection{Landasan Konsep}

\subsubsection{Kerangka Pemikiran}

Paradigma yang digunakan pada penelitian ini merupakan paradigma konstruktivisme memandang realitas kehidupan sosial bukanlah realitas yang natural, tetapi terbentuk dari hasil konstruksi. Karenanya, konsentrasi analisis pada paradigma konstruktivisme adalah menemukan bagaimana peristiwa atau realitas tersebut dikonstruksi, dengan cara apa konstruksi itu dibentuk. Dalam studi komunikasi, paradigma konstruktivisme ini sering sekali disebut sebagai paradigma produksi dan pertukaran makna.

Paradigma konstruktivis memandang ilmu sosial sebagai analisis sistematis terhadap socially meaningfull action melalui pengamatan langsung dan terperinci terhadap pelaku sosial dalam kehidupan 
sehari-hari yang wajar atau alamiah, agar mampu memahami dan menafsirkan bagaimana para pelaku sosial yang bersangkutan menciptakan dan memelihara atau mengelola dunia sosial mereka.

\subsubsection{Paradigma Interpretif}

Metode penelitian adalah teknik-teknik spesifik dalam penelitian. Sedangkan, metodologi penelitian adalah proses, prinsip, dan prosedur yang kita gunakan untuk mendekati masalah dan mencari jawaban. Dengan ungkapan lain, metodologi adalah suatu pendekatan umum untuk mengkaji mengkaji topik penelitian. Metodologi dipengaruhi atau berdasarkan perspektif teoritis yang kita gunakan untuk melakukan penelitian, sementara perspektif teoritis itu sendiri adalah suatu kerangka penjelasan atau interpretasi yang memungkinkan peneliti memahami data dan menghubungkan data yang rumit dengan peristiwa dan situasi lain. (Mulyana, 2010:145)

\section{METODE}

Fenomenologi adalah studi yang mempelajari fenomena seperti penampakan, segala hal yang muncul dalam pengalaman kita, cara kita mengalami sesuatu, dan makna yang kita miliki dalam pengalaman kita. (Kuswano, 2009:22)

Maurice Natanson mengatakan bahwa istilah fenomenologi dapat digunakan sebagai istilah generik untuk merujuk kepada semua pandangan ilmu sosial yang menempatkan kesadaran manusia dan makna subjektifitasnya sebagai fokus untuk memahami tindakan sosial (Mulyana, 2001: 20-21).

Kuswarno (2009:36), menggambarkan sifat dasar penelitian kualitatif, yang relevan menggambarkan posisi metodologis fenomenologi dan membedakannya dari penelitian kuantitatif:

a. Menggali nilai-nilai dalam pengalaman kehidupan manusia.

b. Fokus penelitian adalah pada keseluruhannya, bukan pada per bagian yang membentuk keseluruhan itu.

c. Tujuan penelitian adalah menemukan makna dan hakikat dari pengalaman,bukan sekedar mencari penjelasan atau mencari ukuan-ukuran dari realitas.

d. Memperoleh gambaran kehidupan dari sudut pandang orang pertama, melalui wawancara formal dan informal.

e. Data yang diperoleh adalah dasar bagi pengetahuan ilmiah untuk memahami perilaku manusia. f. Pertanyaan yang dibuat merefleksikan kepentingan, keterlibatan dan komitmen pribadi dari peneliti.

g. Melihat pengalaman dan perilaku sebagai suatu kesatuan yang tidak dapat dipesahkan, baik itu kesatuan antara subjek dan objek, maupun anatara bagian dari keseluruhan.

\subsection{Penentuan Key Informan:}

Tidak ditemukan dokumen resmi berapa jumlah wartawan angkatan Kembang Jepun Jawa Pos. Hasil wawancara dengan berbagai informan mengungkapkan jumlah wartawan dan redaktur sekitar 25 sampai 30 orang. Di antara mereka sudah banyak yang meninggal dan sangat tua sehingga sulit dijadikan informan. Di antara mereka yang masih bisa dijadikan informan berhasil didata delapan orang key informan yang merupakan redaktur yang sangat intens menggeluti Jawa Pos pada era Kembang Jepun. Mereka semua bersedia menjadi key informan.

Para informan itu adalah:

1. Koesnan Soekandar, usia sekarang 72 tahun, pensiun (wiraswasta, berdagang kecil-kecilan di depan rumah). Jabatan di era Kembang Jepun: Redaktur Ekonomi Bisnis.

2. Selamet Oerip Prihadi, usia sekarang 64 tahun. Dikenal dengan sebutan "Suhu" karena selalu menjadi guru bagi wartawan junior. Sekarang pensiun dan membuka warung kopi di depan rumah. Jabatan di era Kembang Jepun: Redaktur Olahraga.

3. K. Sudirman, usia 63 tahun. Sekarang pensiun dan menjadi agen koran. Jabatan di Kembang Jepun: Koordinator Liputan

4. Djono W. Oesman, usia 56 tahun. Sekarang menjadi penulis di Jakarta. Jabatan di Kembang Jepun: Reporter

5. Surya Aka, 57 tahun. Sekarang bekerja sebagai karyawan swasta. Jabatan di Kembang Jepun: redaktur halaman kota.

6. Abdul Muis, 52 tahun. Sekarang karyawan swasta. Jabatan di Kembang Jepun: reporter olahraga

7. Sholihin Hidayat, 58 tahun. Sekarang menganggur dan terserang stroke. Jabatan di Kembang Jepun: redaktur politik

8. Roso Daras, 58 tahun. Sekarang menjadi penulis di Jakarta. Jabatan di Kembang Jepun: reporter.

Pengumpulan data dilakukan dengan wawancara mendalam (in depth interview) dengan para informan dan triangulasi dilakukan dengan melakukan cross check kepada informan lainnya dan data-data tertulis yang tersedia. 


\section{TEMUAN DAN PEMBAHASAN}

Dari sebuah koran kecil dengan kantor di pinggir sungai Kalimas di ujung Jembatan Merah yang kumuh, Jawa Pos bertransformasi dengan cepat mejadi raksasa media nasional yang disegani. Praktis hanya dalam waktu duapuluh tahun Jawa Pos memenangkan persaingan secara penuh di Jawa Timur. Pada 1990-an Jawa Pos menembus oplah 100 ribu, sementara pesaing utamanya, Surabaya Post, sedang menghadapi sakaratul maut.

Transformasi seperti meteor ini berhutang kepada beberapa formula rahasia yang menjadi andalan Jawa Pos. Tentu saja tidak hanya di bidang redaksi, bidangbidang lain seperti sirkulasi, distribusi, produksi, dan iklan juga mempunyai kontribusi besar dalam kemajuan Jawa Pos. Tetapi, tidak bisa dimungkiri bahwa produk Jawa Pos sebagai koranlah yang menjadi andalan utama.

Koesnan Soekandar masih mengingat pengalamannya dengan jelas bagaimana kualitas penulisan berita menjadi fokus utama pembenahan setiap hari. Semua redaktur dan wartawan setiap pagi harus mengikuti rapat evaluasi mendetail mengenai penulisan dan pembuatan judul. Koesnan termasuk redaktur lama yang sudah bergabung dengan Jawa Pos sebelum Dahlan Iskan masuk. Pada era sebelumnhya, evaluasi dilakukan secara rutin setiap minggu. Tetapi di era baru evaluasi dilakukan setiap hari di pagi hari mulai pukul 07.00 dan bisa berlangsung Daripada berbicara konsep dan filosofi yang mendakik-dakik, Dahlan lebih praktis dan sederhana. Ia langsung memberi contoh bagaimana membuat lead (kepala berita) yang pendek tapi menarik. Ia memberi contoh langsung bagaimana judul yang eye catching (menarik perhatian). (Oesman, 2015).

Setiap media mempunyai formula kebijakan redaksionalnya masing-masing. Kompas dikenal dengan konsep jurnalisme berasaskan humanisme transendental, kemanusiaan yang beriman, memanusiakan manusia (Soelarto, 2001, 2015). Konsep ini sama saja dengan rukun ke-6 Rukun Iman Jawa Pos yaitu daya tarik manusia (human interest). Jawa Pos sangat menekankan pada berita-berita mengenai manusia. Cerita-cerita mengenai manusia selalu menarik, baik ditulis dalam bentuk features maupun profil. Karena itu Jawa Pos selalu menampilkan berita-berita mengenai manusia dan menjadi bagian penting dalam Rukun Iman.

Dalam pengalaman Djono Wikanto Oesman (dwo), Dahlan adalah sosok yang praktis, tidak suka berterori. Sangat berbeda dengan Jakob Oetama, pendiri Kompas, yang dikenal sebagai wartawan intelektual yang selalu sarat dengan referensi ilmiah dalam tulisan-tulisannya. Dahlan orang yang praktis dan membumi. Tulisan-tulisannya sederhana. Tetapi dalam kesederhanaan itulah terdapat kekuatan. Dwo mengalami langsung sentuhan tangan Dahlan hampir setiap pagi hari pada awal-awal masa perkembangan Jawa Pos di Kembang Jepun. Dwo mengisahkan pengalamannya berikut:

'Setiap pagi mulai jam 07.00 wartawan diharuskan kumpul untuk rapat evaluasi dengan Pak Bos, biasanya sampai jam sepuluh atau sebelas. Setiap tulisan dievaluasi mulai dari lead, kutipan, sampai ke judul. Seringkali Pak Bos keras dalam memberi evaluasi. Kalau ada tulisan yang dianggap tidak bermutu, harus siap-siap kena semprot".

Surya Aka adalah redaktur halaman kota pada era Kembang Jepun. Ia mengalami langsung bagaimana kerasnya Dahlan dalam mengevaluasi setiap halaman. Semua judul dilihat dan dievaluasi. Setelah judul dipelototi kemudian lead dibaca semua. Cara membuat kutipan dibaca dan dievaluasi. Peserta rapat ditanya bagaimana pendapat mereka terhadap satu masalah dan dipaksa untuk memberikan alternatif kata atau kalimat.

Pengalaman Slamet Oerip Prihadi (Suhu) sebagai redaktur olahraga juga tidak berbeda dengan redaktur lainnya. Jangan dikira Dahlan tidak membaca beritaberita olahraga. Dahlan membaca semua dengan cermat dan teliti. Jika ada data yang tidak tepat atau ada logika penulisan yang tidak tepat Dahlan langsung mengoreksi. Kebetulan pada masa-masa itu Jawa Pos sedang gencar memberitakan kiprah tim sepakbola Persebaya di kompetisi Divisi Utama Nasional. Cara penulisan bertutur yang runut dengan bahasa sederhana yang khas Surabaya, menjadikan Jawa Pos sebagai rujukan para suporter sepakbola yang ingin mendapatkan informasi mengenai tim kesayangannya. Pada awal 1990, Jawa Pos mengklaim telah menembus oplah 100 ribu. Hal itu disebabkan dua event besar. Yang pertama adalah Revolusi Filipina 1986 dan kedua pertandingan grand final kompetisi sepakbola divisi utama 1987 yang dimenangkan Jawa Pos. Dalam peristiwa Revolusi Filipina Jawa Pos mengirim wartawati Nany Wijaya untuk meliput langsung ke Filipina. Dalam tradisi jurnalistik Indonesia waktu itu masih belum banyak media yang mengirim reporter untuk melakukan liputan luar negeri. Terobosan Jawa Pos ini berhasil menaikkan oplah koran dengan sangat cepat karena liputa-liputan yang eksklusif. 
Dalam kasus final Persebaya 1987, Jawa Pos benarbenar mengeksploitasinya secara maksimal. Jawa Pos mengoordinasikan pengiriman belasan ribu suporter Persebaya yang disebut sebagai Bonek (bondo nekat, modal nekat) ke Jakarta. Program yang dinamai ' $T r e t$ tet tet ke Jakarta" ini berhasil memobilisasi belasan ribu suporter sepakbola Surabaya ke Jakarta, dan pada saat bersamaan Jawa Pos mengekspos habis-habisan semua hal mengenai Persebaya. Jawa Pos memanfaatkan fanatisme publik sepakbola Surabaya dengan menyajikan berita-berita lengkap dan detail mengenai Persebaya. Efek dari eksploitasi itu adalah para suporter menjadi lebih fanatik terhada Persebaya dan Jawa Pos terkena dampak positif sebagai media yang dekat dengan Persebaya. Pada masa-masa itu Dahlan bahkan menjadi manajer tim Persebaya.

K. Sudirman merasakan pengalaman yang berbeda pada masa-masa Kembang Jepun. Ketika itu Sudirman bertugas sebagai koordinator liputan yang harus mengatur alur penugasan liputan wartawan setiap hari mulai pagi hingga larut malam. Semangat untuk mendapatkan liputan yang eksklusif dirasakan oleh Sudirman ada pada para wartawan dan redaktur. Tidur di kantor adalah hal yang dialami sehari-hari karena deadline yang mendekati dinihari. Sering terjadi ada peristiwa tengah malam setelah deadline. Karena peristiwa itu dinilai menarik maka Sudirman harus mengirim reporter dan mengoordinasikan stop press untuk bisa memuat berita terbaru itu. Kalau sudah terjadi peristiwa selepas deadline bisa dipastikan Sudirman harus menginap di kantor.

Roso Daras adalah wartawan flamboyan dengan dandanan yang trendy dan rambut semi-gondrong yang rapi ditambah kumis tebalnya yang khas. Roso sering meliput peristiwa hiburan, seni, dan budaya. Roso adalah penulis features andalan. Ia mengalami bagaimana tulisannya diedit langsung oleh Dahlan meski baru diketik setengah halaman. Dahlan mengedit dan Roso melanjutkan mengetik. Roso bisa mengalami secara langsung bagaimana gaya penulisan yang diinginkan Dahlan.

Abdul Muis (amu) adalah wartawan paling muda di antara generasi Kembang Jepun. Ketika itu umurnya belum jangkap 25 tahun. Ia menjadi reporter olahraga dan ditugaskan meliput Persebaya. Tulisannya sangat kerap diedit langsung oleh Dahlan, karena itu amu bisa mengangsu langsung keterampilan jurnalistik dari Dahlan. Amu mengaku gaya penulisannya merupakan ajaran Dahlan Iskan. Setiap kali tulisan diedit oleh Dahlan, amu memerhatikan dengan saksama.
Esok harinya dia akan membandingkan naskah tulisannya yang asli dan dibandingkan dengan hasil editan Dahlan. Dari situ amu mempelajari gaya jurnalistik Dahlan.

Sebagai anak kandung Tempo, Jawa Pos diarahkan untuk mempunyai gaya penulisan seperti Tempo. Janet E. Steele penulis buku 'The Wars Within; The Story of Tempo Magazine in Soeharto's Indonesia" (2005) mengungkap bagaimana Tempo adalah sebuah pesantren dan Goenawan Mohamad, pemimpin redaksi, adalah kiainya, dan para wartawan Tempo sebagai santrinya. Dahlan adalah salah satu santri Tempo yang kemudian ditugaskan untuk "mendirikan pesantren Jawa Pos". Dahlan ingin mengopi gaya jurnalisme literer (jurnalisme pesantren maka Dahlan belumlah menjadi seorang santri senior, ia baru santri junior. Karena itu dia belum cukup banyak mencecap ilmu dari kiainya. Dengan ilmu jurnalisme literer yang belum khatam itu Dahlan menjadi kiai di Jawa Pos. Maka yang terjadi kemudian gaya penulisan Jawa Pos adalah versi lain yang lebih rendah dari Tempo.

Koesnan mengingat pengalamannya mengenai hal ini. Dia menuturkan:

'Mas Dahlan memberi tahu bahwa gaya penulisan Jawa Pos adalah gaya Tempo harian. Maksudnya, Tempo mempunyai gaya penulisan bertutur dan terbit sebagai mingguan. Jawa Pos juga meniru gaya penulisan bertutur dan terbit harian. Dalam bahasa kita waktu itu Jawa Pos adalah Tempo yang terbit setiap hari’".

Bagaimana pengalaman mereka dengan konsep Rukun Iman? Para informan mengaku bahwa pada era awal Kembang Jepun istilah 'Rukun Iman Jawa Pos" belum secara eksplisit diperkenalkan. Tetapi, enam prinsip Rukun Iman itu secara intensif diperkenalkan oleh Dahlan sejak hari pertama. Baru beberapa tahun kemudian istilah Rukun Iman itu diperkenalkan dan menjadi keyakinan yang terus diugemi. Karena pengalaman bersama yang seragam, pemahaman mengenai Rukun Iman masih tetap dirasakan para informan sampai sekarang hampir tiga puluh tahun kemudian.

Para informan tidak hafal secara runut keenam Rukun Iman. Tetapi mereka hafal di luar kepala dalam mempraktikkannya. Hal itu karena pengalaman yang sangat intesif dalam menerima nilai-nilai Rukun Iman yang dirasakan para informan saat masih di Kembag Jepun. 


\section{KESIMPULAN}

Jawa Pos menjadi fenomena dalam sejarah perkembangan pers di Indonesia. Dari oplah yang hanya 6.000 saat dibeli Tempo pada 1982 Jawa Pos tembus 100 ribu dalam sepuluh tahun, dan kemudian menjadi market leader di Jawa Timur dalam masa sepuluh tahun berikutnya. Peran generasi Kembang Jepun, generasi awal Jawa Pos pada masa awal pertumbuhan, sangatlah penting. Studi ini menunjukkan, bagaimana pengalaman para pioner itu dalam membangun Jawa Pos. Etos kerja keras yang luar biasa menjadi pilar keberhasilan. Tetapi, di balik itu, pengalaman para informan menunjukkan bahwa nilai-nilai berita (news value) yang terangkum dalam 'Rukun Iman Jawa Pos" adalah sebuah secret formula (resep rahasia) sukses Jawa Pos dalam menyajikan produk media yang disukai dan dicintai secara fanatik oleh publik Jawa Timur. (*)

\section{DAFTAR PUSTAKA}

Ahmadi, Abu, 2002. Psikologi Sosial. Jakarta: Rineka Cipta.

Arikunto, Suharsimi. 2010. Prosedur Penelitian: Suatu Pendekatan Praktek. Jakarta: Rineka Cipta.

Atkinson, Rita, L., Richard C. Atkinson, Edward E. Smith, Daryl J, Bem, 2011. Pengantar Psikologi. Tangerang: Interaksara.

Changara, Hafied. 2012. Pengantar Ilmu Komunikasi. Jakarta: Rajawali Press.

Haris Sumadiria, 2005. Jurnalistik indonesia menulis berita dan Feature panduan praktis jurnalis profesional. Bandung: Simbiosa Rekatama Media.

http://profil.merdeka.com/indonesia/j/jawapos, diakses pada 25 April 2016.

Inarto, Joko. 2013. Akal Sehat Dhalan Iskan: Catatan seorang Murid. Yogyakarta: Mitramedia.

Kuswarno, Engkus, 2009. Metodologi Penelitian Komunikasi Fenomenologi: Konsepsi, Pedoman, dan Contoh Penelitian Fenomena Pengemis Kota Bandung. Bandung: Widya Padjadjaran.
Moleong, Lexy. 2007. Metode Penelitian Kualitatif. Bandung: Remaja Rosdakarya.

2005. Metode Penelitian Kualitatif. Bandung: Remaja Rosdakarya.

Mulyana, Deddy, 2004. Metode Penelitian Kualitatif: Paradigma Baru Ilmu Komunikasi Dan Ilmu Sosial Lainnya. Bandung: Remaja Rosdakarya.

Nasution, S, 2005. Metode Research. Jakarta: Bumi Aksara.

Oesman, Djono, W. Pengalaman Saya Dimarahi Dahlan: www.kikcdahlan.wordpress.

Sobur, Alex. 2004. Semiotika Komunikasi. Bandung: PT Remaja Rosdakarya.

Sobur, Alex. 2004. Semiotika Komunikasi. Bandung: PT. Remaja Rosdakarya.

Soelarto, St: Jurnalisme Transendental Kompas: Gramedia, 2001

Soelarto, St: Syukur Tiada Akhir; Jejak Langkah Jakob Oetama: Kompas, 2015.

Spradley, James. 2007. Metode Etnografi, Jogjakarta : Tiara Wacana.

Sukandarrumudi. 2004. Metodologi Penelitian. Yogyakarta: Gadjah Mada University Press.

Tsania, Shalli. 2014. Konstruksi Makna Nebeng (Studi Fenomenologi Mengenai Makna Nebeng Bagi Komunitas Nebengers di Kota Bandung). Bandung. Universitas Komputer Indonesia.

Tubbs, Steward L \& Sylvia Moss. 2006. Human Communication, Konteks-konteks Komunikasi. Bandung : Remaja Rosdakarya.

Vardiansyah, Dani. 2004. Pengantar Ilmu Komunikasi. Bogor: Ghalia Indonesia.

West, Richard dan Lynn H. Turner, 2009. Pengantar Teori Komunikasi Analisis dan Aplikasi (Edisi 3). Jakarta: Salemba Humanika.

Winarso H.P, 2005. Sosiologi komunikasi massa. Jakarta: Prestasi Pustaka.

Wirman, Welly. 2012. Pengalaman Komunikasi dan Konsep Diri Perempuan Gemuk, Journal of Dialectics IJAD. Vol. 2, No, 1. Bandung: Pascasarjana Unpad. 